\title{
Real Exchange Rate Determinants in Nigeria: An Application of Cointegration and Error Correction Model
}

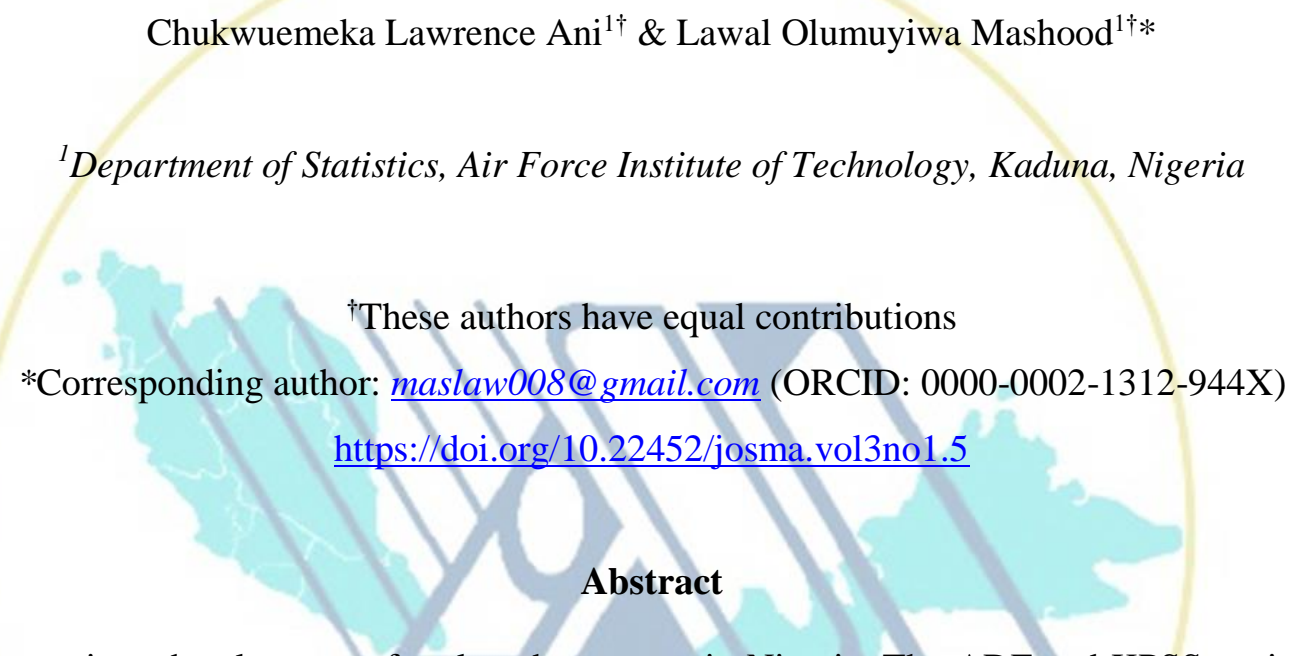

The study examines the elements of real exchange rate in Nigeria. The ADF and KPSS stationarity tests were employed to examine the stationary process of each series and it shows that the macroeconomic variables under study have no stochastic trends, hence, are stationary in levels. The result from Johansen cointegration showed a long-run relationship between real exchange rate and the five explanatory variables. $R^{2}$ of the estimated Fully Modified Ordinary Least Squares (FMOLS) model shows that about $73.39 \%$ of the total variability in real exchange rate has been explained by the independent variables and it further revealed that inflation rate and government expenditure contribute more to exchange rate volatility. Our model adjust its prior periods dis-equilibrium at a speed of $56.98 \%$ annually with the $e c(-1)$ coefficient value - 0.5698; also to achieve long term equilibrium stable state, the VECM shows a significant speed of correction of about $56.98 \%$ for adjusting dis-equilibrium annually. The VECM is well specified and its parameter coefficients are not biased because the ARCH test indicates that it is free from serial correlation and heteroscedasticity. Finally, the strong forces that influence real exchange rate fluctuations in Nigeria as revealed by the Granger causality test are: government expenditure, money supply growth, inflation and real interest rates.

Keywords: Real Exchange Rate Determinants, Granger causality test, macroeconomic variables, disequilibrium, volatility. 


\section{Introduction}

In any economy, the real exchange rate is an essential component that drives export and private investment and ensures stability in the growth of an economy. According to Hamdu (2013) most developing countries ensure that exchange rate policies are used to reduce persistence in misalignment. Hence, to curtail misalignment, it is relevant to ascertain what determines the real exchange rate. Exchange rates between two or more countries play a key role in determining any country's growth, that is, it measures the global competitiveness of a country (Curran and Velic, 2019). When relevant determinants of a country's real exchange rate are not known, it will definitely lose its rate (Kia, 2013). Consequently, understanding the drivers of real exchange rate is absolutely the key for both public and private monetary institutions (De and Sun, 2020). In developing economy such as Nigeria, exchange rate is really a perplexing problem such that, getting currency rates right continue to pose a threat to the economy except monetary institutions will reflects its policies on macroeconomic variables that determines the nation's currency value (Ito, 2017; Ibrahim, 2016). Based on this fact, monetary experts have focused their attention on analyzing factors that influences real exchange rates and how government can sustain growth through internal systems, thereby focusing on local or indigenous economy mechanisms (Wang, 2021).

It is important to note that the Nigerian government has always ensured and continually promote trade through exchange rate and macroeconomic policies as well as engaging in foreign trade in order to encourage the output level and curb instability in the exchange rate (Torbira and Odewale, 2019). Despite all these efforts by different administrations to stabilize and mitigate the constant value dropped by the nation's currency to the US dollar which is a tool for improving the country's export rate and gain popularity in terms of international trade not much has been achieved. Currently, notwithstanding the different measures the recent administration has made to curtail the inability of the Naira to maintain its purchasing power in foreign markets, the current COVID-19 pandemic and the tussle by Organization of the Petroleum Exporting Countries (OPEC) nations to cut down crude oil production as means of maintaining its price has seen the government efforts fruitless. Bhattarai and Armah (2013) point out that the real exchange rate has been used as a tool for regulating flows of trade and capital by many developing economies, which tend to have persistent deficits in the balance of payment because of a structural gap between the volumes of exports and imports.

Bahmani-Oskooee and Gelan (2018) study the exchange rate of twelve developing countries. A short-run relationship was established that real and nominal variables explained real exchange rate, while only real variables were significant in describing real exchange rate in the long-run. The study also shows that real exchange rate change as regards the equilibrium level reveals a negative effect on the association among economic performances and real exchange rate misalignment. Chang and $\mathrm{Su}$ (2014) studied the long-run relationship, the short-run dynamic as well as the direction of causality amongst the macroeconomic 
elements as regards exchange rates for Pacific Rim economies. The study revealed that there is no long run equilibrium for countries under review excluding Taiwan. Chowdhury (2012) adopting Edwards (1989) theoretic framework and applying the ARDL model to examine the elements of the real exchange rate (RER) in Australia. The study period spin from January, 1984 - January, 2011. The work showed that if net foreign liabilities, terms of trade and government expenditures increase it will lead to the increase of the RER for Australia in the long run. While, if interest rates differential, productivity and openness increases, the Australian RER will depreciate.

Essien et al. (2017) evaluated that real exchange rate (RER) misalignment in Nigeria by employing the Behavioral Equilibrium Exchange Rate (BEER) covering the span of the first quarter of 2000 to the first quarter of 2016. The following variables were considered: terms of trade; net foreign assets; government fiscal stance; index of crude oil price volatility; productivity; monetary policy; foreign reserve; and trade openness. Based on the results obtained, it shows that long-run behavior of real exchange rate was directly influenced by the following variables: index of monetary policy performance; index of crude oil volatility; and net foreign assets, while, foreign reserve and government spending are indirectly interrelated to real exchange rate movement. Also, the result shows that an increase in oil revenue could under-value or overvalue real exchange rate in Nigeria. Bhatti et al. (2018) estimated the long run equilibrium real exchange rate for Pakistan economy by employing the annual data to measure Real Effective Exchange Rate (REER) misalignment for the period of 1980 to 2013. Their results showed that government expenditure, productivity and terms of trade increases Pak rupee in the long run. Demirhan and Demirhan (2019) analyze the determinants of nominal exchange rate for Nigeria and 76 other developing countries using the static panel data from 2004 - 2016, applying the pooled OLS, fixed effects, and random effects. The study showed that relative Forex reserves, relative debt and relative money depreciate exchange rate. Abbas et al. (2018) examine the association between external debt and exchange rates of the Pakistani using larger sample size data for the periods 1970 - 2015. They employ Johansen cointegration test and found that terms of trade, productivity and government expenditure are appreciating exchange rate. Furthermore, they investigate the determinants of real exchange rate volatility using General Autoregressive Conditional Heteroscedastic (GARCH) method as well as Error Correction Model (ECM) for long and short runs determinants from 1981 to 2008. They found that government expenditure, openness, lagged exchange rate and interest rate were the main factors of real exchange rate (Ajao and Igbokoyi, 2013).

Kia (2013) generated a monetary model of the real exchange rate employing 1972:Q1 - 2010:Q3 of Canada. The result showed that in the long run domestic and foreign interest rate, real money supply, real government expenditure, real GDP, deficit per GDP, domestic and foreign outstanding debt per GDP, domestic and foreign externally financed debt per GDP and commodity price is a factor affecting real exchange rate. Silvester et al. (2018) in their study measured the direction and extent of misalignment on 
the basis of a reduced form real effective exchange rate (REER) model using unit root tests and cointegration techniques. Money supply, openness, government spending and productivity have long run relationship with exchange rate and the ECM reveals a short-run relationship with a speed of adjustment of $85 \%$.

Most studies on exchange rates in Nigeria either focuses on the impact of exchange rate volatility on trade or on growth as well as comparing the official and parallel markets rate (Yusuf et al. 2019; Musa et al., 2019). Some studies focuses on exchange rate depreciation and volatility employing GARCH model (Ajao, 2015). While, Oriavwote and Oyovwi (2012) consider the causal relationship among (real exchange rate, capital flow, price level, nominal effective exchange rate, ratio of government spending to GDP, terms of trade and technological progress). Furthermore, some of the studies on real exchange rate focuses on nonlinear estimation and endogenous structural breaks such as (Ani and Umar, 2020; Ani et al., 2020).

This paper will apply the Johansen cointegration, Vector Error Correctional Model (VECM) as well as Granger causality (or "G-causality") test in evaluating Nigeria's real exchange rate in that way seeking to determine the long-run stable association between the variables and to evaluate the selected determinants. This study will also measure the speed of adjustment for attaining a steady state position and finally, examine causality amongst the study variables.

\section{Materials and Methods}

This study employed yearly observations on real exchange rate, money supply growth rate, real GDP growth rate, inflation rate, real interest rate and Government expenditure (annual percentage) in Nigeria covering the fiscal years from January, 1960 to January, 2020. It takes into account a sample size of 60 years (i.e. 60 numbers of yearly observations) from the period of 1960-2020 obtained from Central Bank of Nigeria (CBN) statistical bulletin (2015). The study seeks to evaluate real exchange rate in Nigeria by considering some selected determinants; these include money supply growth rate, real GDP growth rate, inflation rate, real interest rate and government expenditure using EVIEWS statistical software.

\subsection{Theoretical Framework}

Currently, the recent administration has put different measures in place to ensure Naira maintain its purchasing power in foreign markets. But the current COVID-19 pandemic and the Organization of the Petroleum Exporting Countries (OPEC) nations tussle to maintain crude oil's price by cutting down on its production has made the government efforts fruitless. Real exchange rate does not always or most times do not reflect an exact theoretical framework in order to derive a particular model or prototypical process for empirical calculation. These are in recent times possible in current econometric technique of the 
Vector Autoregression (VAR) study. The VAR principle can be employed to study the empirical association between these variables (i.e. stationarity test and cointegration technique). This can be identified from current studies on the impact of exchange rate variations on output (e.g. Rasool et. al., 2021; Balogun, 2017; Robert et. al, 2018; Kassem et. al 2019). Still, a thorough theoretical framework is exceedingly imperative to explicitly comprehend the fundamental structure through which the concerned variables impact on any specific outcome. Also, it can help to ascertain the suitable associations amidst a set of likely relations frequently described by a theoretical VAR estimates.

Among frameworks, in studying the impact of stabilization programme on aggregate production in developing nations generated a valuable model relating exchange rate to overall output. The analytic tool became one of the peak important frameworks in empirical examination on the effects of output devaluation. Following the three market Keynesian model; an additional valuable framework is Rhodd (1993). Thus, this study seeks to adopt the Rhodd (1993) theoretical framework; this framework will be used to derive an abridged system of equation for the empirical evaluation.

Applying the Rhodd's model, the goods market is characterized by:

$$
T E=C E+D I E+S+G S+X-M
$$

Alternatively,

$$
\begin{gathered}
T E-C E-G S=D I E+X-M \\
S=I_{j}+I_{l} \\
S=S(T E, D I R) ; \frac{\partial S}{\partial T E}>0, \frac{\partial S}{\partial D I R}>0 \\
I_{j}=I_{j}(T E, D I R) ; \frac{\partial I_{j}}{\partial T E}>0, \frac{\partial I_{j}}{\partial D I R}<0 \\
I_{l}=I_{l}(T E, E R) ; \frac{\partial I_{l}}{\partial T E}<0, \frac{\partial I_{l}}{\partial E R}>0 ; \quad I_{l T E}<0, I_{l E R}>0
\end{gathered}
$$

Where, total expenditure, consumption expenditure, domestic investment expenditure, savings, government spending, net exports $\left(I_{l}\right)$ or domestic investment $\left(I_{j}\right)$, domestic interest rate and exchange rate are represented respectively by $T E, C E, D I E, S, G S, X-M, D I R$, and ER. Eq. (3) displays the equilibrium among aggregate demand and supply; whereas Eqs. (4), (5) and (6) indicate by what means $S$, $I_{j}$ and $I_{l}$ are solved in the model. Domestic investment $\left(I_{j}\right)$, that explains net buildup of assertions on $(X$ $M$ ) is projected to fluctuate reversely in respect to domestic income and positively to $E R$. Thus, rise in TE may spur imports as well which leads to the worsening of $X-M$. Also, growth in ER will definitely increase trade balance. 
Taking into consideration the money market, the equilibrium needs the corresponding of money demand and supply. Monetary policy will be certainly determined by money supply and money demand by interest rate and income.

$$
M_{S}=M_{j}
$$

$M_{j}=U(T E, D I R) ; U_{T E}=\frac{\partial M_{j}}{\partial T E}>0, U_{D I R}=\frac{\partial M_{j}}{\partial D I R}<0$

The foreign exchange market provides the equilibrium of demand of foreign exchange in contrast to supply. In a static exchange rate system, balance of payments is typically controlled by trade and financial flows. As the level of income increases, trade balance gets worsen (Rhodd, 1993).

$$
\begin{aligned}
& B=T(T E)+V(D I R) \\
& \frac{\partial B}{\partial T E}<0, \frac{\partial B}{\partial D I R}<0
\end{aligned}
$$

In solving the model algebraically, the equilibrium conditions on the goods market, on the monetary market and on the foreign exchange market can be expressed respectively in linear functions as:

$$
\begin{gathered}
S_{0}+S_{1} T E+S_{2} D I R-I_{j 0}-I_{j 1} T E-I_{l 2} D I R-I_{l 0}-I_{l 1} T E-I_{l 2} E R=0 \\
U_{0}+U_{1} T E+U_{2} D I R=M_{s} \\
T_{0}+T_{1} T E+T_{2} E R+V_{0}+V_{1} T E+V_{2} D I R-B=0
\end{gathered}
$$

Eqs. (11), (12) and (13) can be translated into matrix as shown below:

$$
\left(\begin{array}{ccc}
\left(S_{1}-I_{j i}-I_{l 1}\right) & \left(S_{2}-I_{l 2}\right) & 0 \\
U_{1} & U_{2} & 0 \\
\left(T_{1}+V_{1}\right) & V_{2} & -1
\end{array}\right)\left(\begin{array}{c}
T E \\
D I R \\
B
\end{array}\right)=\left(\begin{array}{c}
-S_{0}+I_{j 0}+I_{l 0}+I_{l 2} E R \\
M_{s}-U_{0} \\
-T_{0}-T_{2} E R-V_{0}
\end{array}\right)
$$

Based on Eq. (14), TE is given as:

$$
T E=\frac{\left(U_{2} S_{0}-U_{2} I_{j 0}-U_{2} I_{l 0}-U_{2} I_{l 2} E R+M_{S} S_{2}-U_{0} I_{l 2}\right)-\left(S_{2} U_{0}+I_{l 2} M_{S}\right)}{D}
$$

Where, $D=\left(U_{1}\right)\left(S_{2}-I_{l 2}\right)-\left(U_{2}\right)\left(S_{1}-I_{j 1}-I_{l 1}\right)>0$

$$
\frac{\partial T E}{\partial E R}=\frac{-U_{2} I_{l 2}}{D}>0 ; \quad U_{2}<0, I_{l 2}>0, \text { and } D>0
$$

Hence, our empirical methods will reflect Eq. (15) that shows the relationship between real exchange rate and the highlighted determinants.

\subsection{Model Specification}

In this study, the empirical description will closely follow the theoretical framework as shown in section 2.1. Thus, the theoretical model signifies a long-run relationship amongst the study variables as 
highlighted in this paper. We employ cointegrating regression model using fully modified ordinary least squares (FMOLS) to investigate the impact of macroeconomic variables on real exchange rate in Nigeria. The model characterising the association among real exchange rate (RER), real GDP growth rate (RGDP), money supply growth rate (M2), inflation rate (IFR), real interest rate (RIR) and government expenditure (annual percentage) (GEX) presented and specified as follows:

$$
R E R=f(R G D P, M 2, I F R, R I R, G E X)
$$

The functional model is specified as follows:

$$
R E R_{t}=\beta_{0}+\beta_{1} R G D P_{t}+\beta_{2} M 2_{t}+\beta_{3} I F R_{t}+\beta_{4} R I R_{t}+\beta_{5} G E X_{t}+\varepsilon_{t}
$$

Where: $R E R_{t}=$ Real exchange rate at time $t ; R G D P_{t}=$ Real GDP growth rate at time $t ; M 2_{t}=$ Money supply at time $t ; I F R_{t}=$ Inflation rate at time $t ; R I R_{t}=$ Real interest rate at time $t ; G E X_{t}=$ Government expenditure annual growth rate at time $t ; \beta_{0}=$ Intercept of the regression equation; $\varepsilon_{t} \sim N(0,1)$ is the random error term, and $\beta_{1}, \beta_{2}, \ldots, \beta_{5}$ are the slope coefficients of the independent variables in the model which expresses the linear component of the model.

The study expects the slope coefficients $\left(\beta_{1}, \beta_{2}, \ldots, \beta_{5}>0\right)$ to be positive for the independent variables to have positive impacts on the response variable.

\subsection{Estimation Procedure}

This section presents the estimation procedure of data analysis for this research work. Specifically, the section presents Augmented Dickey Fuller (ADF) unit root test, Kwiatkowski-Phillips-Schmidt-Shin (KPSS) stationarity test, Johansen cointegration test, normalized cointegrating regression model using the fully modified ordinary least squares (FMOLS) method, vector error correction model (VECM), Autoregressive Conditional Heteroscedastic (ARCH) Heteroscedasticity test and causality test based on Toda-Yamamoto technique.

\subsubsection{Augmented Dickey Fuller Stationarity Test}

In computing the test statistics, the following Augmented Dickey-Fuller regression model Eq. (19), is a generalized autoregression model formulated by Dickey and Fuller (1979), and is used. To differentiate a unit root, the following regression can be run:

$$
\Delta Y_{t}=b_{0}+\sum_{j=1}^{k} b_{j} \Delta Y_{t-j}+\beta t+\gamma Y_{t-1}+\varepsilon_{t}
$$

Where: $b_{0}$ is the intercept, $\beta$ the coefficient on a time trend, and $k$ the lag order of the autoregression. The regression comprises sufficient lags of $\Delta Y_{t}$ as a result $\varepsilon_{t}$ comprises no autocorrelation. If a time trend is 
not required then the model can be use without $t$. In the wake of a unit root, differentiating $Y_{t}$ is paramount which should result in a white-noise series (no correlation with $Y_{t-1}$ ).

The Augmented Dickey-Fuller (ADF) test; $H_{0}: \gamma=0$ against $H_{1}: \gamma \neq 0$. Therefore, the test statistic for $H_{0}: \gamma=0$ is

$$
Z_{t}=\frac{\hat{\gamma}}{\hat{\sigma}_{\gamma}}
$$

Where $\hat{\sigma}_{\gamma}$ is the standard error of $\hat{\gamma}$.

\subsubsection{Kwiatkowski-Phillips-Schmidt-Shin (KPSS) Stationarity Test}

Although ADF unit root test is one of the power conventional unit root tests with reasonable size distortions and good power property. We employ a more powerful non-parametric stationarity test; Kwiatkowski-Phillips-Schmidt-Shin (1992), to confirm the results of the ADF unit root test.

In Kwiatkowski-Phillips-Schmidt-Shin (KPSS) stationarity test, the null hypothesis is that an autoregressive representation of each variable is stationary. An alternative for this hypothesis is that the autoregressive representation of each variable contains a unit root. A rejection of the null hypothesis means the series is non-stationary while failure to reject the null implies that the series is stationary.

The series $Y_{t}$ is assumed to be trend-stationary under the null hypothesis. The KPSS statistic is based on the residuals from the OLS regression of $Y_{t}$ on the exogenous variables $X_{t}$ :

$$
Y_{t}=X^{\prime}{ }_{t} \theta+u_{t}
$$

The Lagrange Multiplier $(L M)$ statistic is defined as:

$$
L M=\sum_{t} S(t)^{2} / T^{2} f_{o}
$$

Where $f_{o}$ is an estimator of the residual spectrum at frequency zero and $S(t)$ is a cumulative residual function.

\subsubsection{Johansen cointegration Test}

This technique is applied when the variables under study are integrated of the same order, then the Johansen cointegration is appropriate to examine the long run equilibrium relationship, Tursoy (2019). Thus, the test procedure is given below:

Consider a Vector Autoregressive (VAR) model of order $p$ :

$$
Y_{t}=\Phi_{1} Y_{t-1}+\Phi_{2} Y_{t-2}+\cdots+\Phi_{p} Y_{t-p}+B X_{t}+\varepsilon_{t}
$$

Where $Y_{t}$ is the $k$-vector of non-stationary $I(1)$ variables, $X_{t}$ is the $d$-vector of deterministic variables and $\varepsilon_{t}$ is a vector of innovations. 


\subsubsection{Vector Error Correction Model (VECM)}

The one period lagged ECM that integrates short run dynamics in the long run relationship is stated below;

$$
\begin{aligned}
& \Delta R E R_{t}=\alpha_{1}+\sum_{i=1}^{p} \beta_{1 i} \Delta R G D P_{t-1}+\sum_{i=1}^{p} \beta_{2 i} \Delta M 2_{t-1}+\sum_{i=1}^{p} \beta_{3 i} \Delta I F R_{t-1}+\sum_{i=1}^{p} \beta_{4 i} \Delta R I R_{t-1}+ \\
& \sum_{i=1}^{p} \beta_{5 i} \Delta G E X_{t-1}+\lambda E C_{t-1}+\varepsilon_{2 t}
\end{aligned}
$$

Where:

$E C_{t-1}$ : denotes the error correction term that gives the response as well as the adjustment effect, showing the level of the disequilibrium correction.

$\varepsilon_{2 t}$ : denotes error term.

\subsubsection{VAR Causality Test (Modified Wald Test)}

Since, cointegration test do not tell us the direction of the relationship between the study variables, we employ Wald test procedure to determine the direction of causality among the study variables. To conduct Granger causality test based on Wald procedure, we set up a 2-equation VAR model in the levels of the data, including an intercept in each equation as follows:

$$
\begin{aligned}
& Y_{t}=\alpha_{1}+\sum_{i=1}^{k+d} \beta_{1 i} Y_{t-i}+\sum_{t-i}^{k+d} \beta_{2 i} X_{t-i}+\varepsilon_{x t} \\
& X_{t}=\alpha_{2}+\sum_{i=1}^{k+d} \phi_{1 i} X_{t-i}+\sum_{t-i}^{k+d} \phi_{2 i} Y_{t-i}+\varepsilon_{y t}
\end{aligned}
$$

Where $k$ denotes the highest lag order; $d$ denotes the utmost integration order; $\varepsilon_{x t}$ and $\varepsilon_{y t}$ denotes the error.

\section{Results and Discussion}

In analyzing time series data, we first plot the original series in level against time which help us in understanding the trend as well as pattern of movement of the original series. The plots of the original series are reported in Figure 1. 

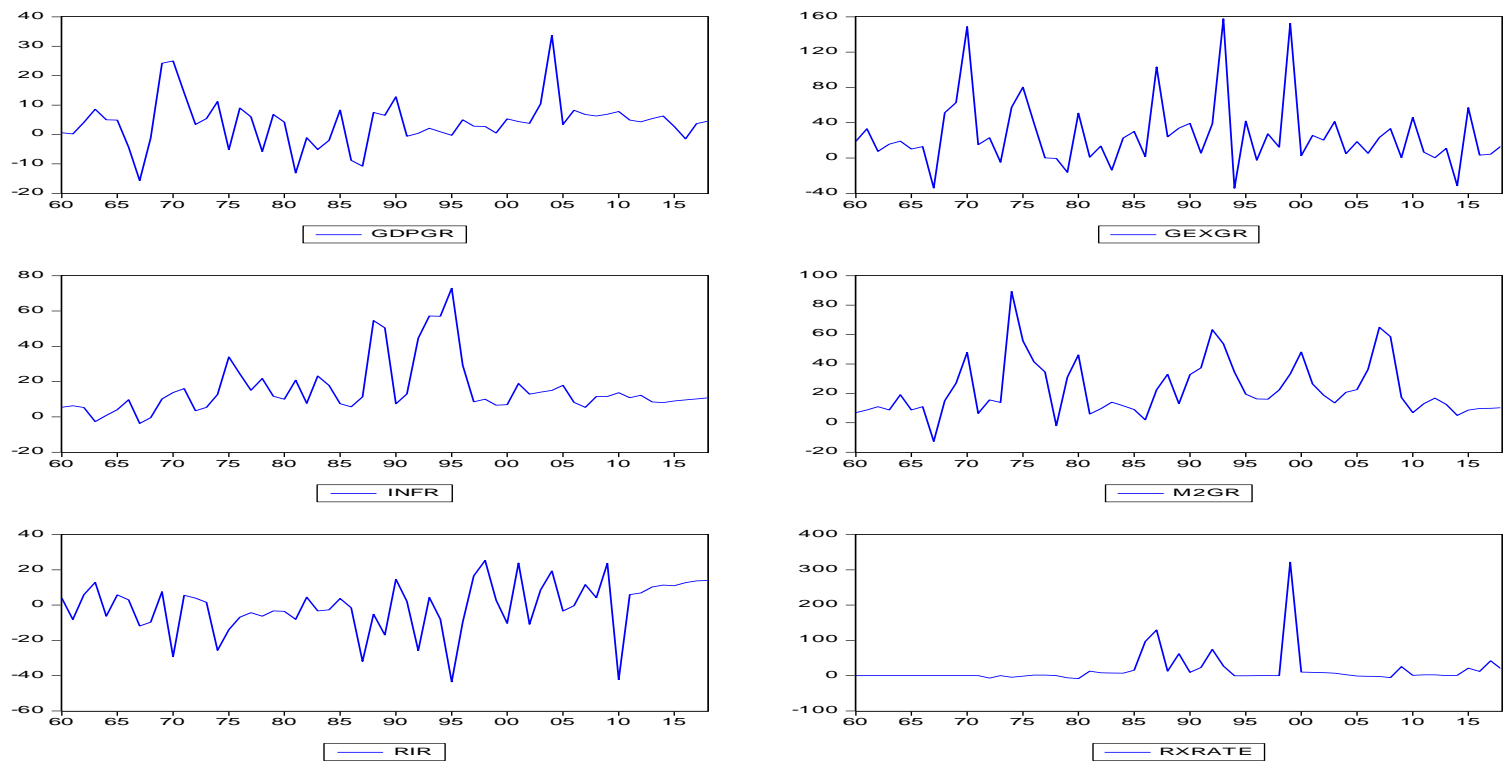

Figure 1: Time Plots of GDP Growth Rate, Government Expenditure Growth Rate, Inflation Rate, Money Supply Growth Rate, Real Interest Rate and Real Exchange Rate in Levels.

From the time plots of the study variables reported in Figure 1, it shows clearly that the trend movements in all the plots are very smooth. This indicates that their means and variances do not change with time (homoscedastic) and the series seems to be covariance stationary. We further investigate the stationarity of the study variables using unit root and stationarity test.

\subsection{Stationarity Test}

The ADF and KPSS stationarity test results are presented in Table 1 and Table 2.

Table 1: ADF Unit Root Test Results

\begin{tabular}{|c|c|c|c|}
\hline Variables & Option & Test Statistic & P-Value \\
\hline \multirow{2}{*}{$\boldsymbol{e r}$} & Intercept only & -9.1070 & $0.0000 *$ \\
\cline { 2 - 4 } & Intercept and trend & -9.0467 & $0.0000 *$ \\
\hline \multirow{2}{*}{$\boldsymbol{g d \boldsymbol { p }}$} & Intercept only & -15.7796 & $0.0000 *$ \\
\cline { 2 - 4 } & Intercept and trend & -14.3485 & $0.0000 *$ \\
\cline { 2 - 4 } & Intercept only & -8.8792 & $0.0000 *$ \\
\hline \multirow{2}{*}{$\boldsymbol{i n f r}$} & Intercept and trend & -8.9038 & $0.0000 *$ \\
\cline { 2 - 4 } & Intercept only & -10.5560 & $0.0000 *$ \\
\hline $\boldsymbol{m} \mathbf{2 r}$ & Intercept and trend & -10.0054 & $0.0000 *$ \\
\cline { 2 - 4 } & Intercept only & -9.7882 & $0.0000 *$ \\
\hline \multirow{2}{*}{$\boldsymbol{e x}$} & Intercept and trend & -9.9878 & $0.0000 *$ \\
\cline { 2 - 4 } & Intercept only & -8.7030 & $0.0000 *$ \\
\hline
\end{tabular}

* denotes the significant of ADF test statistic at 1\%, 5\% and 10\% significance levels. 
From the results of ADF unit root presented in Table 1, by including intercepts only and intercepts and a linear trend, the null hypotheses of unit roots are rejected at 1\%,5\% and $10 \%$ significance levels for all the series under investigation. These results suggest that the macroeconomic variables under study are stationary. This means that the variables do not contain unit roots and hence are stationary in levels.

Table 2: KPSS Stationarity Test Results

\begin{tabular}{|c|c|c|c|c|c|}
\hline Variable & Option & $\begin{array}{l}\text { KPSS } \\
\text { test statistic }\end{array}$ & $\begin{array}{l}1 \% \\
\text { critical value }\end{array}$ & $\begin{array}{l}5 \% \\
\text { critical } \\
\text { value }\end{array}$ & $\begin{array}{l}10 \% \text { critical } \\
\text { value }\end{array}$ \\
\hline \multirow[t]{2}{*}{ rer } & Intercept only & 0.2341 & 0.7390 & 0.4630 & 0.3470 \\
\hline & Intercept and trend & 0.0134 & 0.2160 & 0.1460 & 0.1190 \\
\hline \multirow[t]{2}{*}{$g d p$} & Intercept only & 0.1399 & 0.7390 & 0.4630 & 0.3470 \\
\hline & Intercept and trend & 0.0916 & 0.2160 & 0.1460 & 0.1190 \\
\hline \multirow[t]{2}{*}{ rir } & Intercept only & 0.2516 & 0.7390 & 0.4630 & 0.3470 \\
\hline & Intercept and trend & 0.0138 & 0.2160 & 0.1460 & 0.1190 \\
\hline \multirow[t]{2}{*}{$i n f r$} & Intercept only & 0.2265 & 0.7390 & 0.4630 & 0.3470 \\
\hline & Intercept and trend & 0.0929 & 0.2160 & 0.1460 & 0.1190 \\
\hline \multirow[t]{2}{*}{$m 2 r$} & Intercept only & 0.1235 & 0.7390 & 0.4630 & 0.3470 \\
\hline & Intercept and trend & 0.0139 & 0.2160 & 0.1460 & 0.1190 \\
\hline \multirow[t]{2}{*}{ gex } & Intercept only & 0.1288 & 0.7390 & 0.4630 & 0.3470 \\
\hline & Intercept and trend & 0.0899 & 0.2160 & 0.1460 & 0.1190 \\
\hline
\end{tabular}

The result of the KPSS stationarity test as presented in Table 2 means that the KPSS stationarity test result fails to reject the null hypothesis of stationarity of the entire determinants at the same levels at all the conventional test sizes both with constant only and with constant and linear trend at 1\%, 5\% and $10 \%$ significance levels.

Since both the ADF unit root and KPSS stationarity tests results confirmed that all the study macroeconomic variables are stationary in level, it is worth concluding that the study variables are integrated of order zero, $I(0)$. 


\subsection{VAR Lag Order Selection Criteria}

Table 3: VAR Lag Order Selection Criteria

\begin{tabular}{|c|c|c|c|c|c|c|}
\hline Lag & LogL & LR & FPE & AIC & SIC & HQC \\
\hline $\mathbf{0}$ & 758.49 & $N A$ & $2.54 e-09$ & -8.4398 & -8.0781 & -8.2931 \\
\hline $\mathbf{1}$ & 1179.55 & 798.8241 & $2.48 e-11$ & -13.0692 & $-12.4181 *$ & $-12.8051 *$ \\
\hline $\mathbf{2}$ & 1199.94 & $37.7440 *$ & $2.36 e-11 *$ & $-13.1193 *$ & -12.1789 & -12.7379 \\
\hline $\mathbf{3}$ & 1210.84 & 19.6900 & $2.51 e-11$ & -13.0611 & -11.8313 & -12.5622 \\
\hline
\end{tabular}

Note: * indicates lag order selected by the criterion.

The result of the VAR lag order selection criteria reported in Table 3. The selected lag order by each of the criteria considered are as follows: LR $(p=2)$; FPE $(p=2)$; AIC $(p=2)$; SIC ( $p=1)$; and HQC $(p=1)$. Therefore, the lag length for $P=2$ will be used from now on in this study.

\section{Table 4: VAR Residual Serial Correlation LM Test}

\begin{tabular}{|l|l|l|}
\hline Lags & LM-Stat & P-value \\
\hline $\mathbf{1}$ & 17.7833 & 0.3367 \\
\hline $\mathbf{2}$ & 25.4822 & 0.0618 \\
\hline $\mathbf{3}$ & 16.1053 & 0.4456 \\
\hline $\mathbf{4}$ & 17.5334 & 0.3519 \\
\hline $\mathbf{5}$ & 13.5929 & 0.6290 \\
\hline $\mathbf{6}$ & 21.6761 & 0.1540 \\
\hline $\mathbf{7}$ & 15.5517 & 0.4847 \\
\hline $\mathbf{8}$ & 17.2649 & 0.3687 \\
\hline $\mathbf{9}$ & 27.4158 & 0.3371 \\
\hline $\mathbf{1 0}$ & 23.3820 & 0.1039 \\
\hline $\mathbf{1 1}$ & 20.0774 & 0.2168 \\
\hline $\mathbf{1 2}$ & 22.5420 & 0.1265 \\
\hline
\end{tabular}

Table 4 showed that the estimated VAR for lag order selection criteria is dynamically stable since all the p-values of the LM-test statistics are not statistically significant $(p>0.05)$. 


\subsection{Johansen Cointegration Test}

Having confirmed that the variables under investigation are all integrated of the same order (i.e., $I(0)$ ), we are now in a better position to explore their long-run stable relationships using Johansen cointegration testing procedure. The results of both trace and maximum eigenvalue tests are reported in Table 5 .

Table 5: Summary of Johansen Cointegration Test Results

\begin{tabular}{|c|c|c|c|c|c|}
\hline \multicolumn{6}{|c|}{ Trace Test } \\
\hline $\begin{array}{l}\text { Hypothesized } \\
\text { No. of CE(s) }\end{array}$ & $H_{0}$ & $H_{1}$ & $\begin{array}{c}\text { Trace } \\
\text { Statistic }\end{array}$ & $\begin{array}{c}\text { Critical } \\
\text { Value }\end{array}$ & P-value** \\
\hline None $*$ & $r=0$ & $r \geq 1$ & 173.1688 & 117.7082 & 0.0000 \\
\hline At most $1 *$ & $r \leq 1$ & $r \geq 2$ & 120.8260 & 88.8038 & 0.0000 \\
\hline At most $2 *$ & $r \leq 2$ & $r \geq 3$ & 76.0319 & 63.8761 & 0.0034 \\
\hline At most $3 *$ & $r \leq 3$ & $r \geq 4$ & 46.0467 & 42.9153 & 0.0235 \\
\hline At most 4 & $r \leq 4$ & $r \geq 5$ & 23.1637 & 25.8721 & 0.1048 \\
\hline At most 5 & $r \leq 5$ & $r=6$ & 9.3605 & 12.5180 & 0.1593 \\
\hline \multicolumn{6}{|c|}{ Maximum Eigenvalue Test } \\
\hline $\begin{array}{l}\text { Hypothesized } \\
\text { No. of CE(s) }\end{array}$ & $H_{0}$ & $H_{1}$ & $\begin{array}{c}\lambda_{\max } \\
\text { statistic }\end{array}$ & $\begin{array}{c}\text { Critical } \\
\text { Value }\end{array}$ & P-value** \\
\hline None $*$ & $r=0$ & $r=1$ & 52.3427 & 44.4972 & 0.0058 \\
\hline At most $1 *$ & $r \leq 1$ & $r=2$ & 44.7942 & 38.3310 & 0.0079 \\
\hline At most 2 & $r \leq 2$ & $r=3$ & 29.9852 & 32.1183 & 0.0891 \\
\hline At most 3 & $r \leq 3$ & $r=4$ & 22.8830 & 25.8232 & 0.1166 \\
\hline At most 4 & $r \leq 4$ & $r=5$ & 13.8032 & 19.3870 & 0.2676 \\
\hline At most 5 & $r \leq 5$ & $r=6$ & 9.3605 & 12.5180 & 0.1593 \\
\hline
\end{tabular}

Trace test shows 4 cointegrating equations and Max-eigenvalue test shows 2 cointegrating equations at the 0.05 level of significance.

From the result of Johansen cointegration trace test reported in the upper panel of Table 5, the statistical null hypotheses of no cointegration are rejected at $r=0, r \leq 1, r \leq 2$ and $r \leq 3$. The trace test specifies 4 cointegrating equations at the 0.05 significance levels. Whereas the maximum eigenvalue test reported in the lower panel of Table 5, the statistical null hypotheses of no cointegration are rejected at $r=0$ and $r \leq 1$. The maximum eigenvalue cointegration test indicates 2 cointegrating equations at the 0.05 significance levels. 
The results of the trace and maximum eigenvalue cointegration results established the presence of a long run equilibrium relationship amongst the variables. That is, the Trace statistics establish a solid evidence about the relationship existing between real exchange rate and its determinants, this is due to the fact that, in case of five (5) co-integrating equations four out of five rejected the null hypothesis of noncointegration. Thus, cointegration amongst the variables under study appears in four cases according to trace statistics of Johansen cointegration technique.

Accordingly, our findings on cointegration time series as regards our study variables, we have established strong evidence in rejecting the null hypothesis of non-cointegration which is of crucial importance in explaining equilibrium real exchange rate behaviour. This means that real exchange rate; real GDP growth rate, real interest rate, inflation rate, money supply growth rate and government expenditure growth rate are all cointegrated and hence shared a common stochastic trend. Furthermore, the cointegration test has established the fact that macroeconomic variables do influence real exchange rates in Nigeria. In effect, the results reported in Table 5 clearly indicate that the existence of a long-run relationship between real exchange rates and the highlighted determinants in this study is largely confirmed at a 5\% level of significance. However, we can categorically state that the theoretical relationship between real exchange rate; real GDP growth rate, real interest rate, inflation rate, money supply growth rate and government expenditure growth rate can strongly confirmed an average long-run cointegrating relationship for other macro-economic variables not identified in this study.

\subsection{Parameter Estimates of Cointegrating Model Coefficients}

In evaluating the influence of real GDP growth rate, inflation rate, real interest rate, money supply growth rate and government expenditure growth rate on real exchange rate, we apply the cointegrating regression equation using fully modified ordinary least square (FMOLS) method. The residuals obtained from this model is saved and use in estimating the vector error correction model. The parameter estimates of the cointegrating multiple regression equation is presented in Table 6.

Table 6: FMOLS Parameter Estimates of the Study Variables

\begin{tabular}{|c|c|c|c|c|}
\hline Variables & Coefficient & Std. Error & t-statistic & Prob. \\
\hline $\boldsymbol{C}$ & 11.1175 & 9.5735 & 1.1613 & 0.2507 \\
\hline $\boldsymbol{g} \boldsymbol{d} \boldsymbol{p}$ & -1.8054 & 0.7175 & -2.5163 & 0.0149 \\
\hline $\boldsymbol{g} \boldsymbol{e} \boldsymbol{x}$ & 0.7328 & 0.1556 & 4.7084 & 0.0000 \\
\hline $\boldsymbol{i n f r}$ & 0.4744 & 0.0815 & 5.8177 & 0.0000 \\
\hline $\boldsymbol{m} \boldsymbol{2} \boldsymbol{r}$ & 0.3442 & 0.1330 & 2.5884 & 0.0134 \\
\hline $\boldsymbol{r i r}$ & 0.3845 & 0.3216 & 2.6265 & 0.0176 \\
\hline
\end{tabular}


Journal of Statistical Modeling and Analytics

Vol 3(1), 55-77. 2021

$R$-squared $\quad 0.7339$

Adjusted R-squared $\quad 0.6711$

F-statistic $\quad 5.3141$

$\operatorname{Prob}($ F-statistic $) \quad 0.0005$

Log likelihood $\quad-298.8979$

Durbin-Watson stat 2.0486

From the parameter estimates of cointegrating multiple regression coefficients reported in Table 6, it is observed that the intercept of the regression model is positively related to real exchange rate, although not statistically significant. This means that real exchange rate is predicted to be $11.12 \%$ holding the explanatory variables constant. The slope coefficient of real GDP growth rate $(g d p)$ is negative and statistically significant at 5\% significance level. This means that an increase in real GDP growth rate by $1 \%$ will leads to a corresponding decrease of real exchange rate by $1.81 \%$ implying that real GDP growth rate has negative and significant impact on real exchange rate in Nigeria. The slope coefficients of real interest rate $($ rir), inflation rate (infr), money supply growth rate $(m 2 r)$ and government expenditure growth rate (gex) all have positive impacts on real exchange rate and are statistically significant at 5\% significance level. This means that by increasing real interest rate (rir), inflation rate (infr), money supply growth rate $(m 2 r)$ and government expenditure growth rate $(g e x)$ by $1 \%$, real exchange rate is predicted to increase by $0.38 \%, 0.47 \%, 0.34 \%$, and $0.73 \%$ respectively in the long-run. The implication is that real interest rate, inflation rate, money supply growth rate and government expenditure growth rate having a direct and significant impacts on real exchange rate in Nigeria.

The coefficient of determination $\left(\mathrm{R}^{2}\right)$ of the estimated model shows that about $73.39 \%$ of the total variability in real exchange rate (rer) has been explained by the independent variables in the model and the overall fitness of the cointegrating regression model is good and adequate. The Durbin Watson statistic value of 2.05 which is greater than $\mathrm{R}^{2}$ and $\mathrm{R}^{2}$ adjusted indicates that our model has no positive serial correlation.

\subsection{Parameter Estimates of Vector Error Correction Model}

One of the basic conditions for estimating a vector error correction model is that the study variables must be cointegrated. When the study variables are cointegrated, they shared a common stochastic drift and are in a state of equilibrium. To break this equilibrium, the residuals from the cointegrating regression equation in Table 6 will be use to evaluate the VECM. The result of the VECM is presented in Table 7. 
Journal of Statistical Modeling and Analytics

Vol 3(1), 55-77. 2021

Table 7: Parameter Estimates of VECM Model

\begin{tabular}{|c|c|c|c|c|}
\hline Variable & Coefficient & Std Error & t-statistic & P-value \\
\hline$c$ & 4.6673 & 10.4948 & 0.4447 & 0.6586 \\
\hline$\nabla r e r(-1)$ & -0.0674 & 0.1416 & 0.4756 & 0.6366 \\
\hline$\nabla g d p$ & -2.0674 & 0.8064 & -2.7635 & 0.0082 \\
\hline$\nabla g d p(-1)$ & -0.6992 & 0.7787 & -0.8979 & 0.3739 \\
\hline$\nabla g e x$ & 0.8498 & 0.1576 & 5.3926 & 0.0000 \\
\hline$\nabla g e x(-1)$ & 0.3718 & 0.1991 & 1.8678 & 0.0682 \\
\hline$\nabla i n f r$ & 0.1195 & 0.5404 & 0.2211 & 0.8260 \\
\hline$\nabla i n f r(-1)$ & 0.4178 & 0.4549 & 0.9185 & 0.3631 \\
\hline$\nabla m 2 \mathrm{r}$ & -0.9666 & 0.3719 & -2.5989 & 0.0085 \\
\hline$\nabla m 2 r(-1)$ & -0.5413 & 0.4404 & -1.2291 & 0.2253 \\
\hline$\nabla r i r$ & 0.9548 & 0.4274 & 2.1677 & 0.0324 \\
\hline$\nabla r i r(-1)$ & 1.1962 & 0.4159 & 2.8770 & 0.0061 \\
\hline$e c(-1)$ & -0.5698 & 0.0975 & -5.8427 & 0.0000 \\
\hline
\end{tabular}

$R$-squared

0.6667

Adjusted R-squared $\quad 0.5392$

F-statistic

6.6602

$\operatorname{Prob}(F$-statistic)

0.0009

Log likelihood

$-287.8213$

Durbin-Watson stat

2.2804

From the result of the VECM reported in Table 7, the slope coefficients are called short-run equilibrium coefficients while $e c(-1)$ is the long-run equilibrium coefficient known as the error correction coefficient.

The short-run equilibrium coefficients show the proportions at which the preceding period's disequilibrium is been corrected. In our VECM, the system corrects its previous period's disequilibrium at the speed of $6.74 \%$ between real exchange rate and real exchange rate lag one year, $206.74 \%$ between real exchange rate and real GDP growth rate, 69.92\% between real exchange rate and real GDP growth rate lag one year, $84.98 \%$ between real exchange rate and government expenditure growth rate, $37.18 \%$ between real exchange rate and government expenditure growth rate lag one year, $11.95 \%$ between real exchange rate and inflation rate, $41.78 \%$ between real exchange rate and inflation rate lag one year, $96.66 \%$ between real exchange rate and money supply growth rate, $54.13 \%$ between real exchange rate 
and money supply growth rate lag one, $95.48 \%$ between real exchange rate and real interest rate and $119.62 \%$ between real exchange rate and real interest rate lag one year. The slope coefficients of $\nabla g d p$, $\nabla g e x, \nabla m 2 r$ and $\nabla r i r$ are statistically significant in the current year indicating that the impacts of real GDP growth rate, government expenditure growth rate, money supply growth rate and real interest rate on real exchange rate are time-based.

In our model the $e c(-1)$ coefficient is -0.5698 . This value is negative as expected signifying that the scheme corrects its preceding period's disequilibrium at a speed of $56.98 \%$ annually. This implies that the VECM model identifies a sizeable speed of adjustment of $56.98 \%$ for correcting disequilibrium annually for attaining long term equilibrium balanced state point.

\subsubsection{Diagnostic Test for Vector Error Correction Model}

The ARCH tests is employed to investigate the presence of heteroscedasticity in the estimated VECM is presented in Table 8.

\section{Table 8: ARCH Heteroscedasticity Test for Vector Error Correction Model}

\begin{tabular}{|l|c|c|c|c|}
\hline Variables & F-Statistic & Prob. & Chi-Square Statistic & Prob. \\
\hline VECM & 0.8189 & 0.9845 & 52.8412 & 0.8993 \\
\hline
\end{tabular}

* Significant at the 0.05 level

Table 8 shows that the p-values for both F-statistic and Chi-square statistic are not statistically significant indicating that the VECM is free from heteroscedasticity; hence, the variance across the residuals of the VECM is homogenous. By implication, the parameter coefficients of estimated VECM are not biased and the model is well specified.

\subsection{Causality Test Results (Using Wald Modified Test)}

In examining the direction of causality amongst the variables, we adopt the Granger causality test using the Wald modified test. Before estimating the Granger causality test, we firstly estimated VAR model which enables us to establish the number of lags to be included in the Granger causality test as presented in Table 3. Table 9 presents the Granger causality test result. 
Journal of Statistical Modeling and Analytics

Vol 3(1), 55-77. 2021

Table 9: Granger Causality Test Results based on Modified Wald Test

\begin{tabular}{|c|c|c|c|c|}
\hline $\begin{array}{c}\text { Dependent } \\
\text { variable }\end{array}$ & Excluded & Chi-Square & Degree of freedom & P-value \\
\hline \multirow[t]{5}{*}{ rer } & $g d p$ & 3.1727 & 2 & 0.2047 \\
\hline & gex & 10.9812 & 2 & $0.0031 *$ \\
\hline & infr & 9.1572 & 2 & $0.0113 *$ \\
\hline & $m 2 r$ & 12.6598 & 2 & $0.0026 *$ \\
\hline & rir & 8.1005 & 2 & $0.0174 *$ \\
\hline \multirow[t]{5}{*}{$g d p$} & gex & 11.6696 & 2 & $0.0027 *$ \\
\hline & infr & 1.5188 & 2 & 0.4679 \\
\hline & $m 2 r$ & 13.2531 & 2 & $0.0013 *$ \\
\hline & rir & 0.6893 & 2 & 0.7085 \\
\hline & rer & 0.0481 & 2 & 0.9763 \\
\hline \multirow[t]{5}{*}{ gex } & $g d p$ & 11.4316 & 2 & $0.0031 *$ \\
\hline & infr & 3.7934 & 2 & 0.1501 \\
\hline & $m 2 r$ & 8.9726 & 2 & $0.0173 *$ \\
\hline & rir & 0.3691 & 2 & 0.8315 \\
\hline & rer & 4.5731 & 2 & 0.1016 \\
\hline \multirow[t]{5}{*}{ infr } & $g d p$ & 5.4001 & 2 & 0.0672 \\
\hline & gex & 8.7529 & 2 & $0.0153 *$ \\
\hline & $m 2 r$ & 13.9049 & 2 & $0.0010 *$ \\
\hline & rir & 1.0062 & 2 & 0.6047 \\
\hline & rer & 0.0056 & 2 & 0.9972 \\
\hline \multirow[t]{5}{*}{$m 2 r$} & $g d p$ & 0.1741 & 2 & 0.9166 \\
\hline & gex & 12.0599 & 2 & $0.0035 *$ \\
\hline & infr & 0.1087 & 2 & 0.9471 \\
\hline & rir & 0.5948 & 2 & 0.7428 \\
\hline & rer & 4.3876 & 2 & 0.1115 \\
\hline \multirow[t]{5}{*}{ rir } & $g d p$ & 0.9143 & 2 & 0.6331 \\
\hline & gex & 4.4659 & 2 & 0.1072 \\
\hline & infr & 2.6736 & 2 & 0.2627 \\
\hline & $m 2 r$ & 0.5069 & 2 & 0.7761 \\
\hline & rer & 7.9502 & 2 & $0.0185 *$ \\
\hline
\end{tabular}

*denotes significant at $5 \%$ level of significance 
From the results of the Granger causality test presented in Table 9, money supply growth rate, inflation rate and government expenditure growth rate Granger cause real exchange rate in Nigeria since there is a one-way causality running amongst them. There is also a two-way causality between real exchange rate and real exchange rate in turn Granger causes real interest rate. Government expenditure influences real GDP growth rate and money supply; and real GDP growth rate and money supply in turn promotes government expenditure in Nigeria. The economic growth and inflation in Nigeria is Granger caused by too much money in circulation. Also inflation is Granger caused by government expenditure in Nigeria which shows a unidirectional causality running.

In summary, the Granger causality test revealed that money supply, government expenditure, inflation rate and real interest rate are the main determinants of real exchange rate in Nigeria. According to this result, these macroeconomic variables are the strong forces that influence real exchange rate fluctuations in Nigeria.

\section{Conclusion}

This research uses a multivariate cointegration test to estimate the factors contributing to real exchange rate in Nigeria by employing annual secondary data. The trends of the study variables plotted are very smooth such that their means and variances do not change with time (homoscedastic) with the series seems to be covariance stationary. It was further established that the variance across the residuals of the VECM is homogenous and free from heteroscedasticity. The macroeconomic variables under study do not contain unit roots and hence are stationary in levels as contained in the result of the ADF unit root test which then implies that the variables are all integrated of the same order, $I(0)$.

This has placed us in a better position of using Johansen cointegration testing procedure to explore the long-run stable relationships of the variables under investigation; which show that all the variables are all cointegrated and hence shared a common stochastic trend. It was observed from the study that real interest rate, inflation rate, money supply growth rate and government expenditure growth rate have direct and significant impacts on real exchange rate but real GDP growth rate has an indirect and significant impact on real exchange rate in Nigeria. The VECM model identifies a sizeable speed of adjustment of $56.98 \%$ for correcting disequilibrium yearly for attaining long term equilibrium balanced state.

The causality test results based on modified Wald test also showed a unidirectional causality running from money supply growth rate to GDP growth rate and to inflation rate and from government expenditure growth rate to inflation rate. This means that economic growth and inflation in Nigeria is Granger caused by too much money in circulation. Also inflation in the country is Granger caused by government expenditure in Nigeria. To sum it up, the Granger causality test revealed that money supply, government expenditure, inflation rate and real interest rate are the main determinants of real exchange rate in Nigeria. 
From our findings, some important policy implications for the policymakers in Nigeria are identified. The cointegration result shows that there is a long run relationship between real exchange rate and its determinants. This implies that in the long run, all these variables have the potentiality of affecting the movement of real exchange rate. They can lead to improvement or deteriorating in the country's competitiveness, which may positively or negatively affect productivity in the tradable goods sector. Research on this subject area should be constantly carried out to ensure the formulation of policy overtime that will improve the competitiveness of the economy, based on the variables that will be used. Finally, going by the result of the Granger causality, government should take into cognizance past levels (values) of government expenditure, inflation rate and real interest rate when making exchange rate policy for the future.

\section{Competing interest}

The authors declared no conflict of interest

\section{Funding}

None

\section{References}

Abbas, B., Iqbal, S. and Malik, I.R. (2018). FDI, External Debt and Their Impact on Economic Growth of Pakistan: Empirical Evidence Using Larger Sample Size. Journal of Contemporary Management Sciences, 4(1): 50 - 65. http://dx.doi.org/10.2139/ssrn.3121113.

Ajao, M.G. (2015). The Determinants of Real Exchange Rate Volatility in Nigeria. Ethiopian Journal of Economic, 24(2): $43-62$.

Ajao, M.G. and Igbokoyi, O.E. (2013). The Determinants of Real Exchange Rate Volatility in Nigeria. Academic Journal of Interdisciplinary Studies, $\quad 2(1): \quad 459 \quad-\quad 471$. https://doi.org/10.5901/ajis/2013.2n1p459.

Ani, C.L. and Hassan, U.M. (2020). Self-exciting Threshold Autoregressive Model and Endogenous Structural Breaks of Exchange Rate Dynamics in Nigeria: A Bai and Perron Sequential Method. Science World Journal, 15(2): 1 - 10.

Ani, C.L., Egwoh, A.Y. and Hassan, U.M. (2020). Application of Self-Exciting Threshold Autoregressive Model on Exchange Rate in Nigeria: A Comparative Approach. Science World Journal, 15(3): 33 45. https://doi.org/10.47514/swj/15.03.2020.005. 
Journal of Statistical Modeling and Analytics

Vol 3(1), 55-77. 2021

Bahmani-Oskooee, M. and Gelan, A. (2018). Exchange-rate Volatility and International Trade Performance: Evidence from 12 African Countries. Economic Analysis and Policy, 58: 14 - 21. https://doi.org/10.1016/j.eap.2017.12.005.

Balogun, A. (2017). Causality between Government Expenditure and Government Revenue in Nigeria. Asian Journal of Economics and Empirical Research, 4(2): $91 \quad$ - 98. https://doi.org/10.20448/journal.501.2017.42.91.98.

Bhattarai, K.R., and Armah, M. (2013). The Effects of Exchange Rate on the Trade Balance in Ghana: Evidence from Cointegration Analysis. African Journal of Business Management, 7(14): 1126 - 1143.

Bhatti, A.A., Ahmed, T. and Hussain B. (2018). Growth Effects of Real Exchange Rate Misalignment: Evidence from Pakistan. The Pakistan Journal of Social Issues, (Special Issue), 70 - 88.

Central Bank of Nigeria (2015). Statistical Bulletin, Golden Jubilee Edition.

Chang, M-J. and Su, C-Y. (2014). The Dynamic Relationship between Exchange Rates and Macroeconomic Fundamentals: Evidence from Pacific Rim countries. Journal of International Financial Markets, Institutions and Money, $30: \quad 220 \quad-\quad 246$. https://doi.org/10.1016/j.intfin.2014.03.002.

Chowdhury, K. (2012). Modelling the Dynamics, Structural Breaks and the Determinants of the Real Exchange Rate of Australia. Journal of International Financial Markets, Institutions and Money, 22(2): 343 - 358. https://doi.org/10.1016/j.intfin.2011.10.004.

Curran, M. and Velic, A. (2019). Real Exchange Rate Persistence and Country Characteristics: A Global Analysis. Journal of International Money and Finance, 97: $35 \quad-\quad 56$. https://doi.org/10.1016/j.jimonfin.2019.06.001.

De, K. and Sun, W. (2020). Is the Exchange Rate a Shock Absorber or a Source of Shocks? Evidence from the US. Economic Modelling, 89: 1 - 9. https://doi.org/10.1016/j.econmod.2019.10.015.

Demirhan, B. and Demirhan, E. (2019). The factors affecting Nominal Exchange rate for Developing Countries: A Panel Data Analysis. Akademik Arastirmalar ve Calismalar Dergisi (AKAD), 11(20): 41 - 49. https://doi.org/10.20990/kilisiibfakademik.538025.

Dickey, D.A., and Fuller, W.A. (1979). Distribution of the estimators for autoregressive time series with a unit root. Journal of the American Statistical Association, 74(366a): 427 - 431. https://doi.org/10.1080/01621459.1979.10482531.

Edwards, S. (1989). Exchange Rate Misalignment in Developing Countries. The World Bank Research Observer, 4(1): 3 - 21. Retrieved March 16, 2021, from http://www.jstor.org/stable/3986346.

Essien, S.N., Uyaebo, S.O.U. and Omotosho, B.S. (2017). Exchange rate Misalignment under Different Exchange Rate Regimes in Nigeria. CBN Journal of Applied Statistics, 8(1): 1 - 21. http://hdl.handle.net/10419/191701. 
Journal of Statistical Modeling and Analytics

Vol 3(1), 55-77. 2021

Hamdu, A. (2013). Determinants of Real Exchange Rate in Ghana. (Unpublished Master's Thesis). Kwame Nkrumah University of Science and Technology, Ghana.

Ibrahim, W. (2016). Econometric analysis of determinants of real effective exchange rate in Nigeria (1960 - 2015). Timisoara Journal of Economics and Business 9 (1), 62 -80. https://doi.org/10.1515/tjeb2016-0005.

Ito, T. (2017). A New Financial Order in Asia: Will a RMB bloc emerge? Journal of International Money and Finance, 74: 232 - 257. https://doi.org/10.1016/j.jimonfin.2017.02.019.

Kassem, M., Ali, A. and Audi, M. (2019). Unemployment Rate, Population Density and Crime Rate in Punjab (Pakistan): An Empirical Analysis. Bulletin of Business and Economics, 8(2): 92 - 104. https://mpra.ub.uni-muenchen.de/id/eprint/95964.

Kia, A. (2013). Determinants of Real Exchange Rate in a Small Open Economy: Evidence from Canada. Journal of International Financial Markets, Institutions and Money, 23: 163 - 178. https://doi.org/10.1016/j.intfin.2012.09.001.

Kwiatkowski, D., Phillips, P.C.B., Schmidt, P., and Shin, Y. (1992). Testing the null hypothesis of stationarity against the alternative of a unit root: How sure are we that economic time series have a unit root?. Journal of Econometrics, 54(1-3): 159 - 178. https://doi.org/10.1016/03044076(92)90104-Y.

Musa, K.S., Muhammed, A., Mohammed, N. and Adamu, S. (2019). Foreign Exchange Rate and Economic Growth Nexus: New Evidence from Nigeria (1981 to 2017). Journal of Economics and Sustainable Development, 10(18): 145 - 156. https://doi.org/10.7176/JESD.

Oriavwote, V.E. and Oyovwi, D.O. (2012). The Determinants of Real Exchange Rate in Nigeria. International Journal of Economics and Finance, 4(8): $150 \quad-160$. http://dx.doi.org/10.5539/ijef.v4n8p150.

Rasool, H., Maqbool, S. and Tarique, M. (2021). The relationship between tourism and economic growth among BRICS countries: a panel cointegration analysis. Future Business Journal, 7(1), 1 - 11. https://doi.org/10.1186/s43093-020-0048-3.

Rhodd, R.T.G. (1993). The Effect of Real Exchange Rate Changes on Output: Jamaica's devaluation experience. Journal of International Development, 5(3): $291 \quad$ - 303. https://doi.org/10.1002/jid.3380050305.

Robert, M., Chung, Y.S. and Soo, K.G. (2018). Bootstrapping the autoregressive distributed lag test for $\begin{array}{llllll}\text { cointegration. } & \text { Applied } & \text { Economics, } & 50(13): & 1509 & -\end{array}$ https://doi.org/10.1080/00036846.2017.136664.

Silvester, M.W., Odondo, A., and Nyongesa, D. (2018). Real Effective Exchange Rate Volatility and Its Impact on Foreign Direct Investment in Kenya. Asian Journal of Economics, Busiess and Accounting, 6(4): 1 - 20. https://doi.org/10.9734/AJEBA/2018/38008. 
Torbira, L.L. and Odewale, D.A. (2019). Non-oil Export and Exchange Rate Nexus: Implications for Output Growth in Nigeria. Journal of Finance and Economic Research, 4(1): 17 - 53.

Tursoy, T. (2019). The interaction between stock prices and interest rates in Turkey: empirical evidence from ARDL bounds test cointegration. Financial Innovation, $\mathbf{5}(1), \quad 1 \quad-\quad 12$. https://doi.org/10.1186/s40854-019-0124-6.

Wang, Z. (2021). China's Exchange Rate Policy Making: An Introduction. The International Political Economy of China's Exchange Rate Policy Making, pp 1 - 30. https://doi.org/10.1007/978-981-334578-2_1.

Yusuf, W.A, Isik, A. and Salisu, N.I. (2019). Relative Effects of Exchange Rate and Interest Rate on Nigeria's Economic Growth. Journal of Applied Economics and Business, 7(2): 28 - 37. 